1975

\title{
An Archaeological Assessment of the Southern Portion of the Olmos Basin, Bexar County, Texas
}

Anne A. Fox

Follow this and additional works at: https://scholarworks.sfasu.edu/ita

Part of the American Material Culture Commons, Archaeological Anthropology Commons, Environmental Studies Commons, Other American Studies Commons, Other Arts and Humanities Commons, Other History of Art, Architecture, and Archaeology Commons, and the United States History Commons

Tell us how this article helped you.

This Article is brought to you for free and open access by the Center for Regional Heritage Research at SFA ScholarWorks. It has been accepted for inclusion in Index of Texas Archaeology: Open Access Gray Literature from the Lone Star State by an authorized editor of SFA ScholarWorks. For more information, please contact cdsscholarworks@sfasu.edu. 


\section{An Archaeological Assessment of the Southern Portion of the Olmos Basin, Bexar County, Texas}

\section{Creative Commons License}

\section{(c) (i) (8)}

This work is licensed under a Creative Commons Attribution-NonCommercial 4.0 International License 
AN ARCHAEOLOGICAL ASSESSMENT OF THE SOUTHERN PORTION OF

THE OLMOS BASIN, BEXAR COUNTY, TEXAS

\author{
Anne A. Fox \\ (With an Appendix by Thomas R. Hester)
}

The Center for Archaeological Research The University of Texas at San Antonio Archaeological Survey Report No. 9 
TABLE OF CONTENTS

$\begin{array}{lr} & \text { Page } \\ \text { Introduction } & 1 \\ \text { The } 1975 \text { Survey } & 2 \\ \text { Previous Archaeological Work } & 3 \\ \text { Recorded Sites } & 4 \\ \text { Reported Sites } & 10 \\ \text { Recommendations } & 14 \\ \text { Acknowledgements } & 16 \\ \text { Bibliography } & 17 \\ \text { Appendix } & 19\end{array}$

Figures

1. The Southern 0lmos Basin 6

2. The Archaeological Sites in the 9 Southern Olmos Basin

3. Artifacts from the Southern 01mos Basin 12

4. Artifacts from the Southern Olmos Basin 13 
During the months of January and February, 1975, an archaeological survey of the 0lmos Basin from Olmos Dam to Hildebrand Avenue was conducted by the author for the Center for Archaeological Research of the University of Texas at San Antonio. The purpose of the survey was to locate, record, and assess the archaeological importance of any historic and prehistoric sites within the basin. The survey area was limited to lands owned by the Sisters of Charity of the Incarnate Word, but sites reported in the immediately surrounding area have also been noted in order to form a more complete archaeological picture.

The Olmos Basin, with its perennial springs of water, has been an important camping place for thousands of years. From archaeological evidence so far accumulated it appears that man first lived in the area in Paleo Indian times. Profectile points of the Clovis, Plainview and Angostura types (9200-6000 B.C.) have been found in the Basin (Figure 3 ). Evidence of man's presence in the Basin during Archaic (6000 B.C.-1000 A.D.) and Neo-American (1000-1600 A.D.) times has also been documented by the findings of point types representative of these periods (Orchard 1974 and Figure 4) and pottery diagnostic of the latter period (Orchard and Campbel1 1960).

While there do not at this time appear to have been any early Spanish settlements on the Incarnate Word property, a branch of the old Nacogdoches road is reputed to have run through the area and orchard (1974) reports the presence of ruins of an old Spanish outpost just north of the dam. During the 19th century a considerable number and varfety of military units camped in the Basin (Orchard 1974, 1975a; Pierce 1969). 
For a description of sites in the 0lmos Basin before, during and after the construction of the dam, the reader is referred to the paper "Evidences of Early Man from the Vicinity of San Antonio, Texas" published by C. D. Orchard and T. N. Campbell (1954: 456-459).

\section{THE 1975 SURVEY}

The field work was accomplished in a series of on-the-ground surveys which ultimately covered the entire basin within the boundaries of the Incarnate Word property. Areas where sites were known to exist were given spectal attention, but all accessible land was examined as closely as possible, considering local problems such as active springs and heavy grass cover. Swampy conditions in the south-central section of the Basin precluded a careful examination of this area, which is known to have contained prehistoric sites observed in the early part of this century. However, it is apparent from examining early aerlal photographs and maps that extensive changes have been made in the terrain of this area. The sites may well have been covered or heavily disturbed. In the process of recording sites, representative samples of artifacts were collected. These have been catalogued, are described in this report, and will become the property of Incarnate Word College. Site numbers were assigned in sequence as they were recorded by the field party, using a trinomial format in which the first number, 41, represents Texas, the letters BX represent Bexar County, and the last number designates a specific site. The numbers were assigned by the Texas Archeological Research Laboratory in Austin, and copies of the stte reports are on file at the facility as well as at the Center for Archaeological Research, The University of Texas at San Antonio. 
In her memoirs, Mary A. Maverick inferred that Indians were in the area in 1839 (Green 1921: 25-26), and the presence of a group of Indians there as late as 1924 (Orchard 1966) Indicates it was a traditional camping spot for later historic Indian groups as well.

Early Anglo American settlers appear to have begun to use the Basin in the mid-19th century when the threat of Indians in the Immediate area had subsided, and by the late 19th century when George Brackenridge bought the land, developers were selling lots in the Alamo Heights area. Each of these groups has left 1ts own peculiar traces which can be found and used by the archaeologist to help understand the history of the Olmos Basin.

\section{PREVIOUS ARCHAEOLOGICAL WORK}

No professional excavations have been conducted within the olmos Basin. However, during the early part of this century, many relic hunters collected artifacts there and today in San Antonio a number of collections containing material from the area undoubtedly exist in private hands. Local amateur archeologist C. D. Orchard spent many hours recording sites and collecting artifacts throughout the Basin in the $1920^{\prime} \mathrm{s}$ and $1930^{\prime} \mathrm{s}$ and witnessed the wholesale destruction of sites when the 01mos Dam was constructed. Fortunately for the archaeological record, Orchard has carefully preserved his artifacts and records, has published several articles and has otherwise generously shared his knowledge with others interested in the area's prehistory (Orchard 1960, 1966, 1974, 1975; Orchard and Campbe11 1954 and 1960). 


\section{RECORDED SITES}

41 BX 289

"Fernridge", the Brackenridge Home. The one-story east wing, a classic early Texas structure, was built in 1852 by previous owner J. R. Sweet. In 1886 George W. Brackenridge added the three-story English style west wing. The building is important both because of its close association with the history of the basin and because it is a fine, well preserved example of the architecture of the period.

\section{BX 282}

San Antonio Spring. This spring is the traditional head of the San Antonio River. The surrounding land has undoubtedly been used as a camp ground for many thousands of years, but presently the immediate area is subject to perfodic flooding and gravel quarrying operations, which appear to have eliminated all traces of these activities. Site 41 BX 292 to the east (see below) was probably. related to the spring. Numerous military encampments were located in the vicinity during the early 19th century (Pierce 1969: 138-140, 148; Orchard 1974), but no artifacts relating to this perfod were found during the survey.

\section{BX 283}

Historic Quarry. Judging from old maps and aerlal photos, this was probably the last quarry worked in the area. There is no Indication on early maps that the quarry existed in 1890, and on an aerial view taken in 1938 it appears to have but recently ceased operations. The old metal frame bridge which provides access is an interesting structure in its own right, and should be preserved if possible. No artifacts were collected.

41 BX 284

Mill. While this structure has been traditionally called a mill, it is rather small for such a structure and the stream on which it is situated 
appears to be one of the smallest in the basin in terms of size and flow of water. Although I do not believe that it is a "mill", the purpose of the structure is at the present unknown. Possibly it has some connection with the Confederate tannery operation which is mentioned in a letter from F. Giraud, Mayor of San Antonio, to George W. Brackenridge dated September 20, 1874. Further archaeological investigations in the immediate area might reveal more about the dating and use of this structure. No artifacts of any kind were found in the area.

$41 B \times 285$

Historic ruins. Projecting from beneath a trash dump behind the Incarnate Word Convent are the ruins of old stone walls which are probably the remains of buildings constructed here in the middle to late 1.9th century. C. D. Orchard has told the author that he was hired as a young man to help tear down some stone houses in this vicinity. Sister Francis Xavier, IWC Ifbrarian (1975) remembers shacks built by squatters on this hill in the early $1900^{\prime} \mathrm{s}$. No artifacts dating earlier than the 1930's were observed in the area.

\section{BX 286}

Prehistoric quarry/workshop. Located on the steep slope below the Cathedral House property of the Episcopal Church, on the east side of the basin. An outcropping of chert cobbles is found at the site. The cobbles have been battered and broken in quarrying operations, leaving chunks of cobbles and large flakes strewn over the hillside in an area approximately 4 meters by 80 meters. The outcrop may well extend the entire length of the valley on this side of the basin but this is the only point where it falls within the property limits of the survey. No artifacts were collected. 
Figure 1. The Southern Olmos Basin

Recorded archaeological sites on Incarnate Word College Property in the southern 0lmos Basin are indicated, and the official site designations are shown. Reported sites, many of which are destroyed, are indicated with capital letters (A,B...). 
This page has been

redacted because it

contains restricted

information. 
41 BX 287

Possible historic site. A knoll just north of the upper spring on the west side of the basin, yielded a collection of late 19th century pottery sherds, glass bottle fragments and brick. No trace of a structure could be found anywhere in the vicinity, which may indicate it was a random load of trash dumped there at some time. The closest presently known historic structures were located on the hill above, where the Convent now stands (see 41 BX 285). Artifacts collected from this site included fragments of glass bottles, crockery and china wares in popular use in the late 19 th century.

Prehistoric camp sites. The remainder of the sites recorded fall into the category of open camp sites, areas where sizable groups probably camped on a seasonal or semi-sedentary basis over thousands of years. The majority of the artifacts which have been recovered from the olmos Easin were found in the central flood plain on low mounds slightly elevated above floodlevel. Most of the projectile points and tools collected by Arthur Collier and illustrated in this report were found in this particular area.

Originally the entire area between the olmos Dam and Hildebrand Avenue was designated under the area site number 41 BX 24. To help facilitate further work on the Incarnate Word property, it was decided to divide the area Into more discrete sites, retaining the original stte number for the central and largest accumulation of prehistoric materfal. The sites in the open field at the base of the dam should perhaps be included under one number. However, they appear to be discrete areas, and so were recorded separately. 
41 BX 288

In the center of the floodplain, near the upper spring on the west side of the Basin, a slight rise about 60 meters in diameter contains a scattering of chert flakes, snails and burned rock. No artifacts were found which would indicate a date for the site. A sample of chipping debris was collected here.

41 BX 24

An area over 250 meters in diameter elevated approximately one meter above the surrounding flood plain in the center of the basin is strewn with burned rock and chert flakes. This is probably the southern end of the crescentic mound referred to by Orchard and Campbel1 (1960: 457-458) and may be all that remains of the extensive midden area described in that report. Collected from this area were numerous chert flakes, two heavy chert tools, and fragments of mid-19th century pottery and glass.

41 BX 290

A low mound approximately 50 meters in diameter contains chert cores and flakes.

41 BX 291

A small mott of liveoak trees at the base of the dam in the center of the floodplain marks the site where Orchard encountered a group of Indians in 1924 and 1925 (Orchard, 1966). Large depressions in the grove indicate the presence of treasure hunters at some previous time. The surrounding 1800 square meters are littered with chert flakes and the burned and fractured rock remnants of countless hearths.

$41 B X 292$

On a level terrace just west of the barns and north of Fernridge, a cultivated field contalns evidence of a prehistoric occupation. This was probably used in conjunction with the San Antonio Spring, as 
Figure 2. Archaeological Sites in the Southern Olmos Basin.

A, 41 BX 291 is located in a mott of liveoak trees

in front of Olmos Dam; B, 41 BX 282 (San Antonio

Spring); note concrete structure in foreground. 


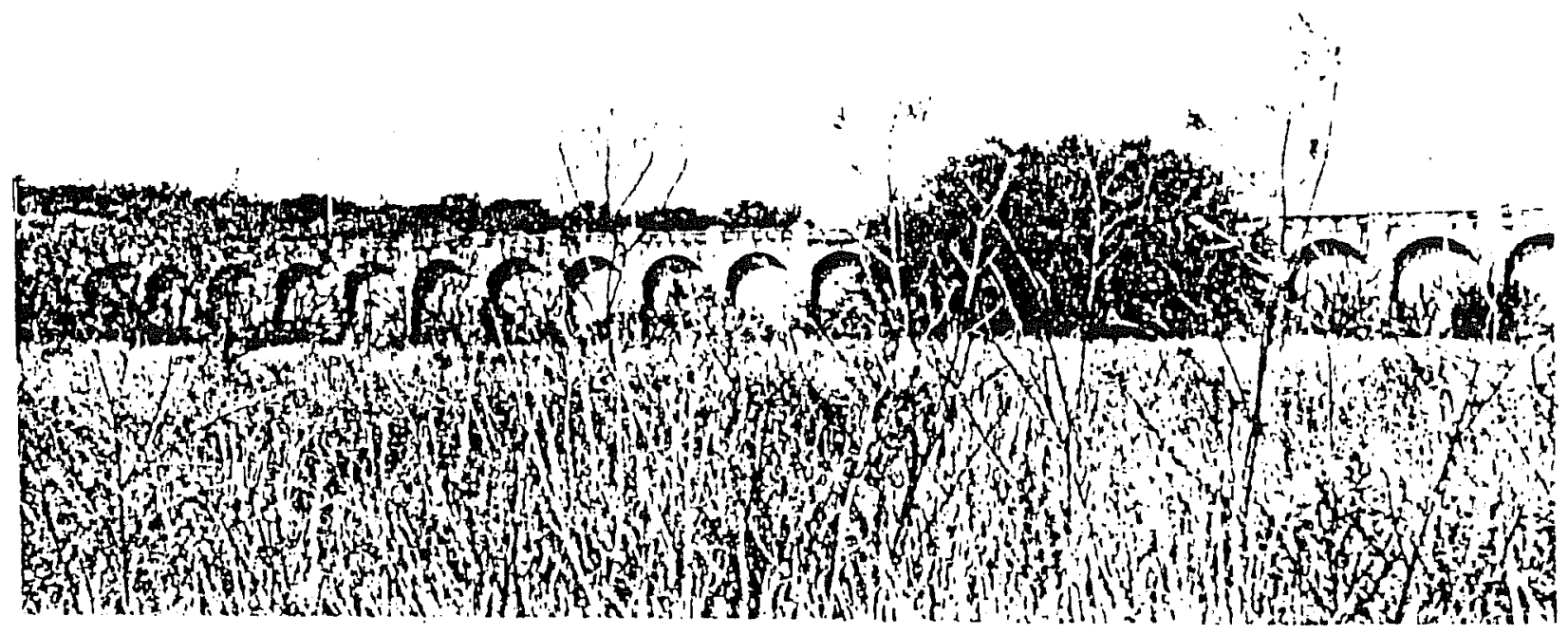

A

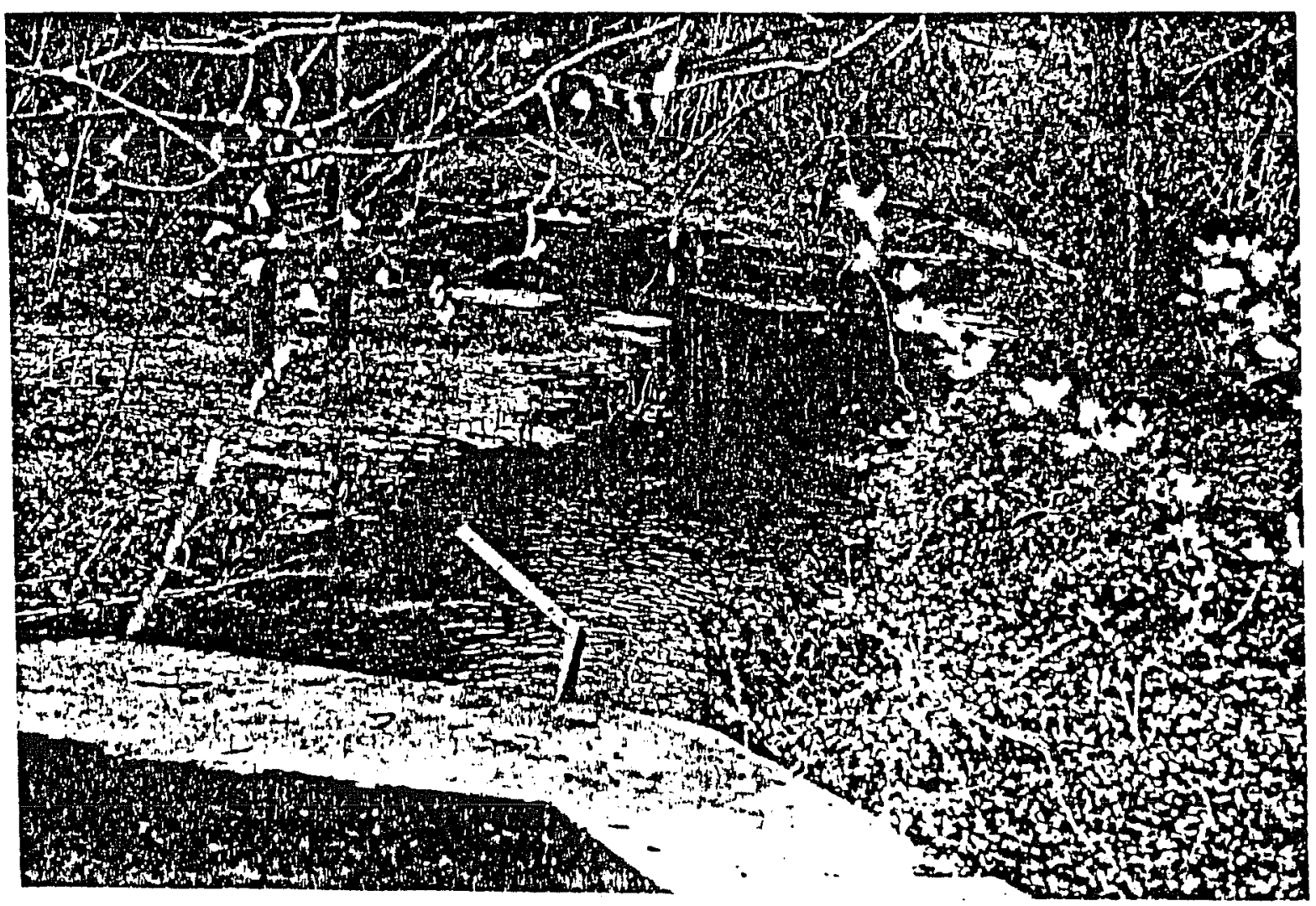


well as being near an unnamed tributary which flows in from the east at this point. Although it is likely that military camps also used this terrace, because of its proximity to the San Antonio Spring, no such evidence was found during the survey.

\section{REPORTED SITES}

The following sites have been reported by reliable informants, but were not confirmed by the survey because of several factors: (1) they are inaccessible, (2) have been destroyed, or (3) are outside the limits of the survey. The areas discussed below are indicated with capital letters $(A, B, C, \ldots)$ in Figure 1 .

(A) Architects Don White and Harvey Smith, Jr. report that numerous Archaic period artifacts were found during excavation for new construction on the Incarnate Word Campus in recent years.

(B) A number of local collectors report that sites containing sherds of Indian pottery were located in this general area. This is not surprising, since pottery has been found elsewhere in the Basin (Orchard \& Campbell 1960: 7). The area in question is presently too swampy to survey, because of recent land filling operations which have completely altered the drainage pattern of the lower Basin.

(C) A large cultivated field in this area, now no longer a part of the Incarnate Word property is reported by Harvey Smith to have contained a large area of flint chipping debris and artifacts.

(D) C. D. Orchard locates the spring where General William Jenkins Worth camped with his troops after returning from the Mexican War, and which became known as Worth's Spring, as just above the east end of the Olmos Dam (Orchard 1974, 1975). 
(E) An old dam located at this point by Orchard in a hand-drawn map (1975) may be the one also mentioned in a letter of agreement between F. Giraud and G. W. Brackenridge of 30 September, 1874, "a dam erected during the Civil War--for the purpose of supplying the Confederate Tannery". 

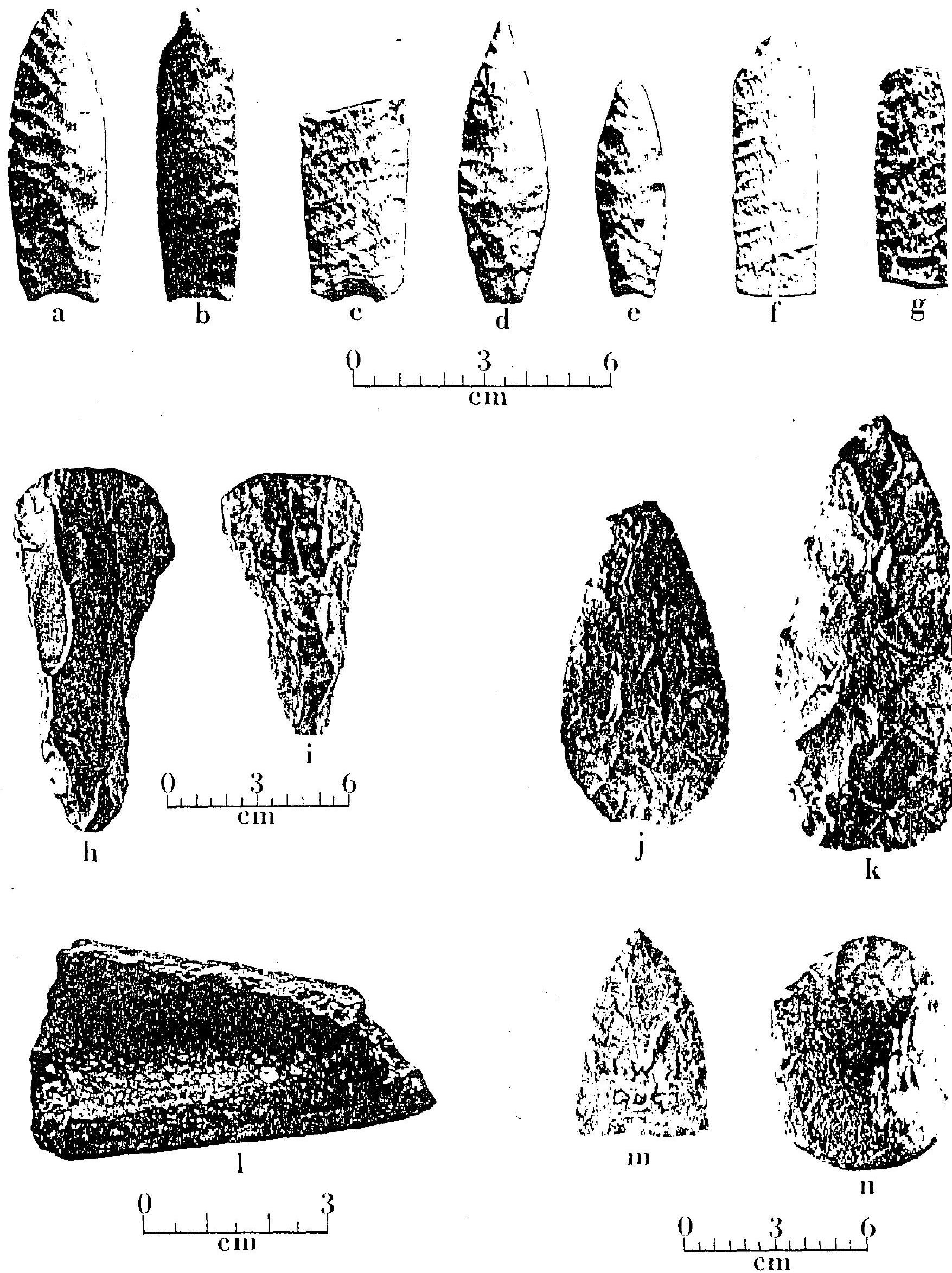
Figure 3. Artifacts from the Southern 01mos Basin a-g, Paleo-Indian: a, Clovis; b, Plainview; c, Golondrina; d,e, Angostura; f,g, paralle1flaked fragments.

h-n, Other Lithic Artifacts: h,i, Guadalupe tools; j,m, thin bifaces; $k$, thick biface; $\ell$, boatstone fragment (top view); n, unifacial tool (scraper) 
Figure 4. Artifacts from the Southern Olmos Basin

a-w, Archaic dart points: a, Bell; b,c, Pedernales; d,e, rectangular stemed; f, Marcos;

g, Fairland; h,i,k, Ensor-Frio; l, m, Ensor;

j, Frio; n,o,p, Langtry; q, Carrizo; r, triangular with deeply concave base; s-u, Tortugas;

$\mathrm{v}$, Catan; w, Desmuke; $\mathrm{x}$, perforator made on Pedernales dart point; $y$-ee, Late Prehistoric (Neo-American) arrow points; y,z, Pcrdiz; aa,bb, Scallorn; cc, Edwards; dd, perforator made on arrow point; ee, triangular 


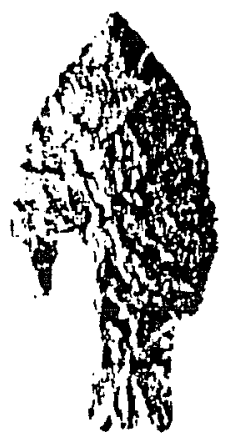

a

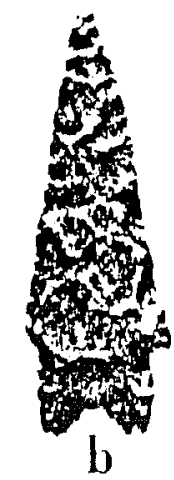

b

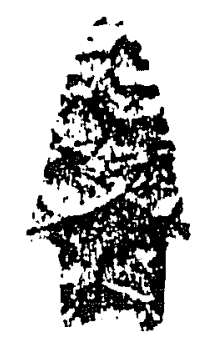

C

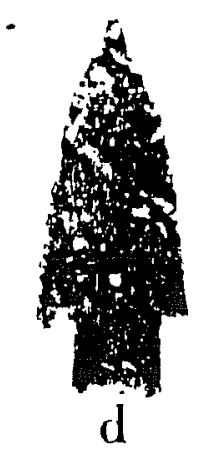

d
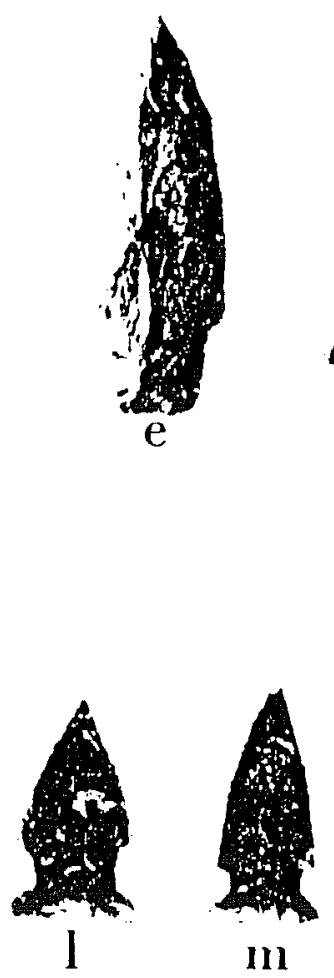

k
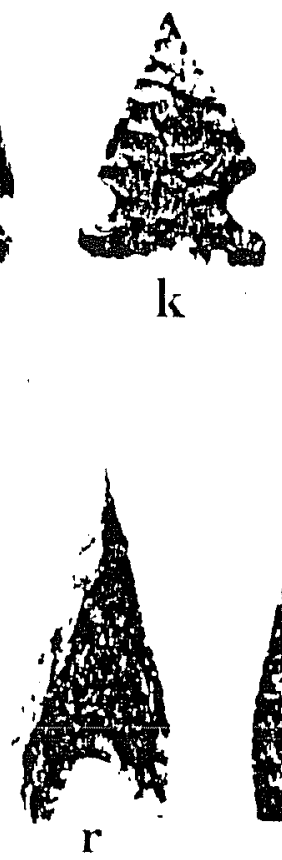

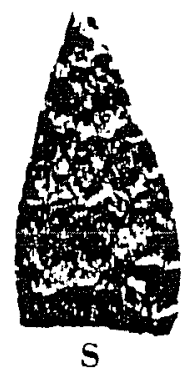

6
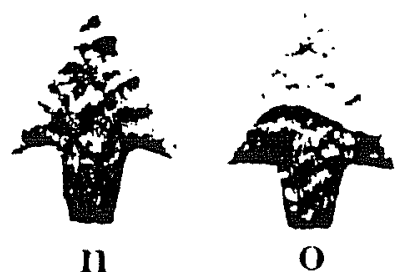

O
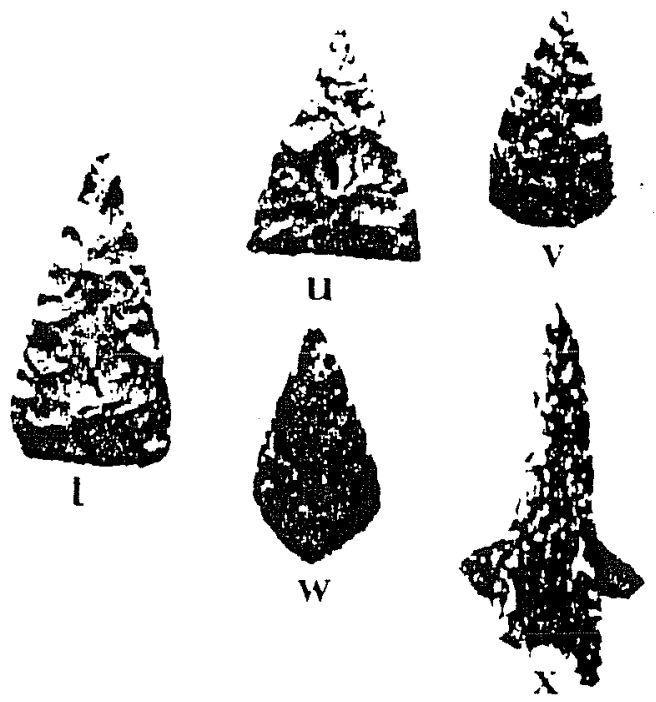
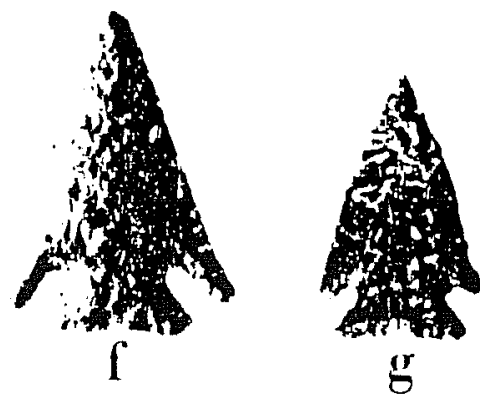

g
$\mathrm{P}$

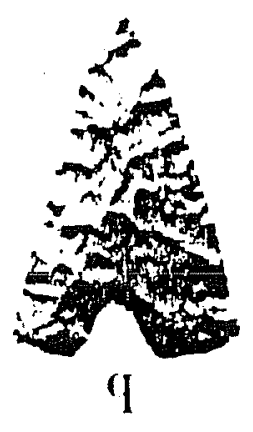

0

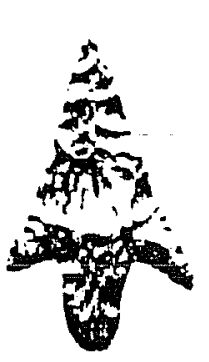

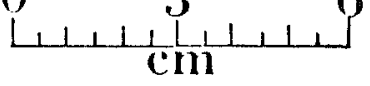
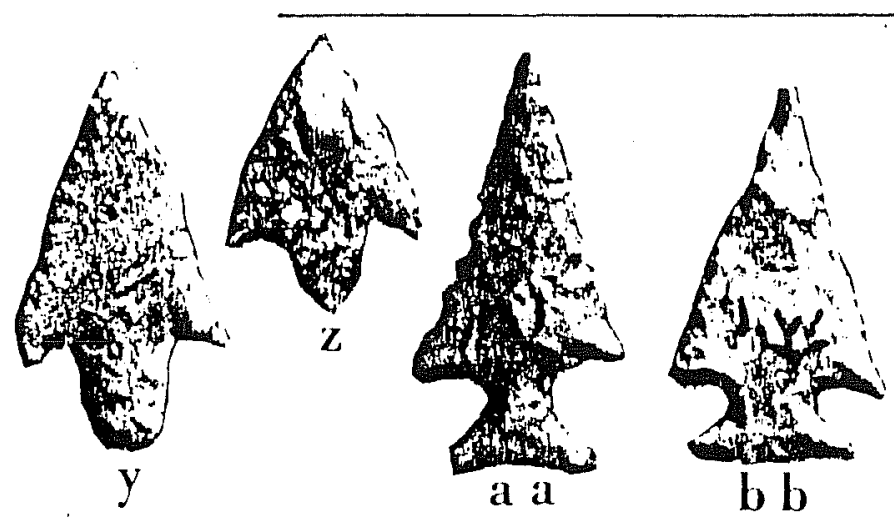

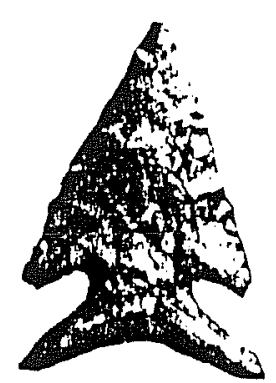

c c

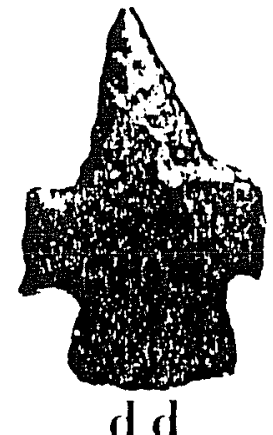

6

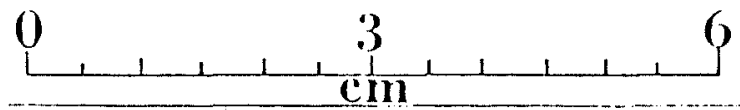

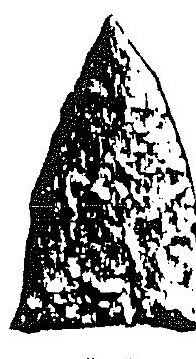

c e 
RECOMRIENDATIONS

This survey of the lower Olmos Basin has yielded a surprising number of archaeological sites which cover a long period of time. A number of projects are recommended to broaden and extend current knowledge of the area's history.

Thorough and meticulous professionally-directed archaeological examination should be given the sites recorded by this survey, particularly those in the area directly below the Dam. Further and more intensive surveys should be carried out in the lower portion of the Basin, just north of Hildebrand Avenue, when a dry period allows access. Hopefully one day the drainage of this area will be restored, allowing a return to the original environment of spring-fed ponds and open meadows. Additional surveys should be done on the east side of olmos Creek, between the Incarnate Word property line and the Dam (with the landowner's permission). Extending research to include the entire Olmos Basin in order to more fully understand its history, the area between the Dam and Tuxedo Road to the north should be surveyed.

All dumping in the Basin should be halted immediately. Steps should be taken to clean up areas where trash has accumulated in such a way that the present drainage system is not altered and that areas of potential archaeological importance are not disturbed.

Historical research in archival collections and deed records would undoubtedly clear up many unanswered questions about the 18 th and early 19th century history of the Basin. A concerted effort should be made, also to locate artifact collectors who have worked in the basin and to document their collections. C. D. Orchard's extensive collection should also be documented. A search for people who lived in the area in 
the early 1900's would undoubtedly turn up a great deal of historical information.

More documentary research and archaeological survey and testing should be dome in the immediate area of the San Antonio Spring and Worth's Spring, to locate the sites of military encampments.

In short, there are more than sufficient unanswered questions in the Olmos Basin to support a continuing program of archaeological and historical research for some years to come. 


\section{ACKNOWLEDGENIENTS}

The author's special thanks go to Betty Dunn of the Development Office of Incarnate Word College for her cooperation and help in providing maps and sharing historical resources. Thanks are also due to Lynn Highley, Mary Frances Chadderdon, Shirley Van der Veer, Eloise Stoker and June Secrist for help in the field survey. C. D. Orchard, Harvey Smith, and A. S. Collier also aided the project by relating their observations of site locations and specific artifacts found and Mr. Collier has generously allowed the documentation of his artifact collection. 


\section{BIBLIOGRAPHY}

Giraud, F.

1874

Letter of agreement perfecting a contract between $F$.

Giraud, mayor, and with G. W. Brackenridge. September 30,1874 .

Green, Rena Maverick, Editor.

1921 Nomoirs of Mary A. Maverich. San Antonio.

McCracken, Dick

n.d. A Honograph on the Incarnate Word Guest House: Brackenridge Villa (1852-1969). San Antonio.

Orchard, C. D.

1966 Two Etcetera Lots in the Orchard Collection. Paper given at Texas Archeological Society meeting.

1974 The Olmos Basin. Unpublished manuscript.

1975a Letter to Anne A. Fox, February 3.

1975b Interview with Anne A. Fox. February 25.

Orchard, C. D. and T. N. Campbell

1954 Evidences of Early Man from the Vicinity of San Antonio, Texas. Texas Journal of Science 6(4): 454-465.

Orchard, C. D. and T. N. Campbell

1960

Southwestern Pottery Sites in the Vicinity of San Antonio, Texas. Texas Archeology 4(2): 7-8.

Pierce, Gerald S. 
Wright, Mrs. S. J.

1916 San Antonio de Bexar. Austin.

Sweet, Alex E. and J. Amory Know

1883 On a Mexican Mustang Through Texas. S. S. Scranton Co., Hartford.

Xavier, Sister Francis

1975 Personal interview with Betty Dunn. 
Appendix

NOTES ON THE COLLIER COLLECTION FROM THE SOUTHERN OLMOS BASIN

Thomas R. Hester

During the course of the Incarnate Word survey, Mr. A. S. Collier (San Antonio) generously made available a portion of his collection from the study area. These materials had been picked up, over the period of many years, from the surface of several recorded sites. Some brief observations on his collection are recorded here with the aim of providing future workers at the Incarnate Word sites with some indication of the kinds of cultural materials they might expect to find.

Paleo-Indian artifacts. Specimens dating from the Paleo-Indian period include: a Clovis point, fluted on both faces (Fig. 3, a), a Plainview point (Fig. 3, b), the basal fragment of a Golondrina specimen (Fig. 3, c), two Angostura points (Fig. 3, d, e), and the distal tips of two parallel flaked projectile point fragments (Fig. 3, f, g). The presence of these artifacts would indicate occupations in the Basin as early as 9,200 B.C. Additional Paleo Indian projectile points from the vicinity are reported by Orchard and Campbell (1954).

Archaic artifacts. By far the bulk of Mr. Collier's collection is attributable to Archaic period occupations (see Fig. 4, a-x). A listing of the recognizable types (and their observed frequencies in the sample) follows: BeCl (1), Catar 11), Carrizo (1), Dcsmukc (1), Ensor (5), Fairand (1) Ficio and Ensor-Frio (7), Langtry (3), Marcos (1), Pederiares (4), and Tortugas $(10)$. Other dart points include these forms: corner notched (2), rectangular stemmed (4), expanding stem (1), contracting stem (1), and triangular (with deep basal concavity; 1). 
The dart points represent the Early, Middle and Late phases of the central Texas Archaic, with the Middle (Pedernales) and Late (Ensor, Frio, Fairland) styles predominating. There is also a noticeable mixture of stemed central Texas dart point styles and the unstemmed forms more characteristic of southern Texas.

Other Iithic artifacts dating largely from the Archaic include a variety of thick bifaces (Fig. 3, k), mostly unfinished specimens or preforms, several thin bifaces which may have functioned as knives. (Fig. 3, j, m) and a few unifacial implements which were probably used as scrapers (Fig. 3, n). Five Guadalupe tools (Fig. 3, h, i) were in the sample that I examined; these artifacts date from Early Archaic (or earlier) times (Hester and Kohnitz 1975). A fragment of a boatstone (spearthrower weight) was also found by Mr. Collier (Fig, 3, L).

Late Prehistoric artifacts. Arrow points (Fig. 4, y-ee) diagnostic of Late Prehistoric (Neo-American) occupations include the Perdiz |3|, Scallorn (4) and Edwards (2) types. A triangular arrow point of a form often linked to the mission Indian period of the early historic period is present in the sample (Fig. 4, ee), as is a unifacially worked specimen which may have actually functioned as a perforator (Fig. 4, dd).

The artifacts in Mr. Collier's collection indicate that human occupation in the southern Olmos Basin began as early as 9,200 B.C. (the period when Clovis points were made) and continued through the prehistoric era. Future work in the sites at Incarnate Word should have several goals in terms of artifact recovery and artifact analysis:

(1) determination of chronological sequence; (2) examination of spatial 
relationships among artifacts found in excavations and in surface collections; (3) collection of accompanying lithic debris; (4) isolation and careful excavation of living floors or strata containing lithic debris of discrete occupations; and (5) the full and careful analysis of all excavated lithics, including debris. Additional information on Basic lithics can be obtained through the comprehensive study of the Collier and C. D. Orchard surface collections.

\section{References Cited}

Hester, T. R. and H. Kohnitz, Jr.

1975 The Chronological Placement of Guadalupe Tools. La Tierra $2(2): \quad 22-25$

Orchard, C. D. and T. N. Campbell

1954 Evidences of Early Man from the Vicinity of San Antonio, Texas Texas Journal of Science 6(4): 454-465. 